\title{
Role of Oxytocin in Deceleration of Early Atherosclerotic Inflammatory Processes in Adult Male Rats
}

\author{
Marwa A. Ahmed, Gehan M. ELosaily* \\ Department of Physiology and Pathology*, \\ Faculty of Medicine, Assiut University, Egypt
}

\begin{abstract}
Objective: The study aimed to examine the effect of exogenous OT administration on the inflammation and atherosclerosis in adult male rats and its possible mechanisms. Thirty adult male rats equally divided into three groups. Control group fed regular diet; group II fed control diet supplemented with L-methionine for 10 weeks. Group III received L-methionine and oxytocin treatment for 10 weeks. RT-PCR analysis showed that OT administration increased oxytocin receptor mRNA (2 fold, P,0.05). Blood samples were evaluated for total homocysteine, interlukin-6(IL-6), monocyte chemoatrratant protein-1 (MCP-1) and C-reactive protein (CRP) by ELIZA. lipid profile, nitric oxide (NO), malondialdehyde (MDA) and reduced glutathione (GSH) were determined. Specimens from aorta were processed for immunohistochemical staining for Aorta nuclear factor_B $(N F-\kappa B)$ p65 protein. Result showed that $O T$ administration to group III decreased the plasma levels IL-6, MCP-1and CRP levels which were elevated in group II. Moreover, there was decrease of the oxidative stress of group III in terms of increased plasma levels of NO and GSH and decreased plasma levels of MDA in blood. In addition, rats of group II showed histological abnormalities manifested by thickening and ulceration of the aortic wall. Marked increased expression of $N F-\_B$ in aorta of in group II was detected. However, OT administration restores the histological structure of the aorta and decreased the expression of $\mathrm{NF}{ }_{-} \kappa \mathrm{B}$ in aorta of group III similar to the control group.

Conclusion: OT has anti inflammatory pathway in atherosclerosis as it decelerates atherosclerosis by decreasing the proinflammatory responses through many mechanisms, mainly the up regulation of its receptors.
\end{abstract}

Key words: oxytocin - atherosclerosis - inflammation- methionine.

\section{INTRODUCTION}

The neurohypophysial peptide oxytocin (OT) is involved in peripheral female reproductive functions, including uterine contraction, lactation and the inflammation stimulated process. It has also been proposed that OT is a cardiovascular hormone that plays an important role in normal homeostatic mechanisms $^{(1)}$. OT and its receptors are synthesized and released in the heart and vasculature of rats and human $^{(2)}$, and these tissues also express oxytocin receptors (OTR $)^{(\mathbf{3})}$.

Homocysteine (Hyc) is a nonprotein thiol containing amino acid, which is produced in the cell as an intermediary in methionine metabolism. ${ }^{(4)}$. 
Several risk factors including hypercholesterolemia, diabetes and tobacco use have been implicated in the onset of atherosclerotic lesions ${ }^{(5)}$ In addition to these established risk factors, epidemiological studies have indicated that elevated plasma levels of Hcy may be an independent risk factor for atherosclerosis and thrombosis $^{(\mathbf{6})}$.

Many studies have correlated associated high plasma or serum concentration of homocysteine with an increased risk of atherosclerosis ${ }^{(7)}$.

Inflammation plays a key role in atherosclerosis (AS) ${ }^{(\mathbf{8})}$. Mild Hyperhomocystinemia (HHcy) by feeding diets rich in methionine or deficient in folate contributes to the early stages of the development of AS by increasing the expression of vascular inflammatory molecules (such as MCP-1 and ICAM-1) and decreasing the availability of nitric oxide $(\mathrm{NO})^{(\mathbf{9})}$.

Animal studies investigating the effects of peripheral OT administration in models of inflammatory diseases have provided evidence for the existence of potentially cardioprotective pathways involving OT. For example, peripheral OT administration has been shown to improve wound healing ${ }^{(\mathbf{1 0})}$.

So, considering possible actions of OT on the inflammation stimulated process, it was hypothesized that treatment with OT may attenuate the proinflammatory process that leads to acceleration of atherosclerosis in a rat model.

\section{Aim of the work:}

The first aim of the current study is to examine the potential antiinflammatory effects of OT involved in the pathophysiology of atherosclerosis. The second aim is to discover the possible mechanisms by which OT can act as antiinflammatory.

\section{MATERIALS \& METHODS}

This study included 30 adult male rats weighing 150-200 gm, were provided from by the Institutional Animal Care and Faculty of Medicine, University of Assiut. They were maintained for a week for acclimatization under conditions of controlled temperature $\left(24-26 \mathrm{C}^{0}\right)$, humidity (55-60\%) and 12 hrs lightdark cycle. They were feed on a standard diet with free access to water. All experimental procedures were carried in accordance with research protocols established by the Animal Care House of Faculty of Medicine, Assiut University, Egypt.

The rats were randomly divided into:

1-Group I: included 10 adult male rats which was fed normal diet.

2-Group: II: included 10 adult male rats, which fed the control diet supplemented with L-methionine 10 $\mathrm{gm} / \mathrm{kg}^{(9)}$ and Food intake was measured daily for 10 weeks.

3-Group III: included 10 adult male rats, which received L- methionine for the same dose as group II and oxytocin in a dose $1 \mathrm{mg} / \mathrm{kg} /$ day intraperotineal $^{(11)}$ for 10 weeks.

Physiologic measurements:

Systolic blood pressure (SBP) was recorded by the tail-cuff device (NARCO, Biosystem, Inc., Huston, Texas) after animals have been warmed for $30 \mathrm{~min}$. in a metabolic chamber maintained at approximately $30^{\circ} \mathrm{C}$. All measurements were made at 
the same time of the day. Mean SBP values obtained from three consecutive measurements were recorded as the pressure values for a given rat at each point.

At the end of the experiment the non-fasting blood samples blood samples $(5 \mathrm{ml})$ from retro -orbital vein were collected in chilled EDTAcontaining microtubes and centrifuged immediately and the plasma were stored at - $20 \mathrm{C}^{\circ}$ until analysis. Then, the rats were killed by decapitation. The thoracic aorta was rapidly removed and dissected from the connective tissues and kept frozen in liquid nitrogen. Tissues were stored in $-80 \mathrm{C}^{\circ}$ until processed.

Other Specimens from aorta were fixed in $10 \%$ netrual- buffered formalin. Sections of 5um were stained with hematoxylin and eosin (H\&E) then were examined with light microscopy for histopathology.

Plasma levels of total cholesterol (C) were determined by colorimeteric method according to the method of Allain $^{(\mathbf{1 2})}$, and triglyceride levels (TG) according to the method of Wahlefeld $^{(\mathbf{1 3})}$. Determination of HDLcholesterol (HDL-C)were done by a microplate enzymatic assay ${ }^{(\mathbf{1 4})}$ using reagents from Synermed International Inc. LDL-cholesterol (LDL-C) was calculated using Friedewald's formula $^{(15)} \quad(\mathrm{LDL}-\mathrm{C}=$ total cholesterol-(HDL-cholesterol-

triglyceride/5) ]. Determination of NO was done by evaluation of its oxidant products, nitrates and nitrites by using Griess reaction ${ }^{(\mathbf{1 6})}$. Plasma levels of malondialdehyde (MDA) were determined as thiobarbituric acid reactivity. The product of reaction between malonic dialdhyde and thiobarbituric acid was measured as described by Ohkawa ${ }^{(17)}$. Determination of reduced glutathione (GSH) levels were determined by HPLC methods according to the Jayatilleke and Shaw ${ }^{(\mathbf{1 8})}$. Plasma total Hcy levels were determined by enzyme-linked immunosorbent assay kit (ELIZA) technique kit according to Frantzen et al ${ }^{(\mathbf{1 9})}$.

Assays for interlukin -6 (IL-6) levels were performed with an ELIZA kit (Endogen, USA) according to the manufacturer's instructions. The assay selectively recognizes IL-6 with a limit of detection of $<1 \mathrm{pg} / \mathrm{ml}$. Plasma monocytes chemoattractant protein1(MCP-1) concentrations were analyzed using a Rat MCP-1 detector kit (Pierce-Endogen). The analysis was conducted according to the manual provided with the kit. Absorbance was detected at $450 \mathrm{~nm}$, using ELISA reader (Bio-TEK Instruments) (20).Determination of plasma levels of C-reactive protein (CRP) were performed with an ELIZA Kit (Helica Biosystems, Inc. Fullerton, CA.). Absorbance was detected at $450 \mathrm{~nm}$.

\section{Immunohistochemistry examination:Aorta nuclear factor_B (NF__ $\kappa$ B) $p 65$ protein.}

Tissue sections (4- $\mu \mathrm{m}$ thick) of formalin-fixed, paraffin-embedded specimens were deparaffinized, rehydrated in graded alcohol, and transferred to PBS (phosphate buffered saline, PH 7.6). The slides were rinsed twice with PBS, then endogenous peroxidase was blocked by the use of $3 \%$ hydrogen peroxide in for $5 \mathrm{~min}$. antigen retrieval was done using microwave at $700 \mathrm{~W}$ for 20 min in citrate buffer. After cooling the 
slides were washed three times with PBS. The slides were incubated for (overnight) at $4 \mathrm{C}$ with prediluted primary antibody. The slides were then rinsed three times with PBS and incubated for $10 \mathrm{~min}$. at room temperature with the biotinylated goat antipolyvalent. The slides were rinsed with PBS for three times and incubated for $5 \mathrm{~min}$. with steptavidin peroxidase at room temperature. The sections were then washed three times with PBS, and diaminibenzidine was applied for $5 \mathrm{~min}$ at room temperature. The slides then rinsed in D.W., counterstained with Mayer's hematoxylin, dehydrated, and then mounted. Negative control were obtained by ommiting the primary antibody. A distinct brown cytoplasmic staining in lipid laden histocytes was scored positive for Nf- $\kappa \mathrm{B}$. Photographs were taken by use of a light microscopy at a magnification of X400.

\section{Semiquantitative reverse transcription-polymerase chain reaction (RT-PCR) :}

Total RNA was isolated from the rat aorta using the Blood Mini Kit (Qiagen, Hilden, Germany).

Following the manufacturer's protocol. The RNA aliquots were stored at $-80^{\circ} \mathrm{C}$ until use. After treatment with deoxyribonuclease I to eliminate possible DNA contamination, the reverse transcriptase reaction was carried out by the Qiagen one step RT- PCR kits by mixing 5-10 $\mathrm{mg}$ total RNA previously denatured at $70^{\circ} \mathrm{C}$ for 10 min in the presence of 10 ul $5 \mathrm{x}$ Qiagen One Step RT- PCR Buffer, 2 ul deoxy-NTPs, $1 \mathrm{ml} 40 \mathrm{U} / \mathrm{ml}$ RNas inhibitor, and 2 ul Qiagen One Step
RT- PCR Enzyme. Then mix with template RNA (2ug/ reaction) using specific primers for OT receptors 5 GTCAATGCGCCCAAGGAAG-3

OTR antisense 5
GATGCAAACCAATAGACACC-3!

GATGCAAACCAATAGACACC-3

,The thermal cycler conditions (Cycler, Bio- Rad Laboratories, Inc., Hercules, USA) of PCR were (denaturation $0.5-1 \mathrm{~min}$ at $94^{0} \mathrm{C}$, anneling for $0.5-1 \mathrm{~min}$ at $55{ }^{\circ} \mathrm{C}$, and extension at $1 \mathrm{~min}$ at $72^{\circ} \mathrm{C}$, The number of cycles was 45 cycles, 370 bp). The PCR products thus obtained were separated by electrophoresis on $1.8 \%$ agarose gel, visualized by ethidium bromide staining under ultraviolet light, and analyzed by scanning densitometry. The results are presented relative to the expression of the control OTR gene. Band intensities of RT-PCR products were quantified using Biometre Image software.

\section{Statistical Analysis:}

All values were expressed as mean \pm SE for all parameters. The data were analyzed by using Prism computer program (Graph Pad version 3.0, Software, Inc., San Diego, CA,USA). For comparison of statistical significance between groups Student Newman Keuls t-test for unpaired data was used. ONE WAY ANOVA test followed by least significance differences LSD were used for multiple comparisons. Levels of significance $(\mathrm{P})$ was considered as follows: $\quad \mathrm{P}>0.05$, not significant. $\mathrm{P} \leq 0.05$, significant and $\mathrm{P} \leq 0.01$, highly significant ${ }^{(21)}$. 


\section{RESULTS}

The mean systolic blood pressure values of group II were significantly higher $(\mathrm{P}>0.001)$ than those of groups I\& III through the weeks of the study. In addition, the BP values in adult rats treated with OT were nearly similar to those of control group. figure (1).

The mean plasma levels of total cholesterol of group I, II and III were $(102.1 \pm 0.28, \quad 102.5 \pm 0.38$ and $102.3 \pm 0.34 \mathrm{mg} / \mathrm{dl}$ respectively). The mean plasma levels of triglyceride levels of group I, II and III were $(79.75 \pm 0.19,79.16 \pm 0.25 \quad$ and $79.97 \pm 0.2 \mathrm{mg} / \mathrm{dl}$ respectively). The mean plasma concentrations of HDL$\mathrm{C}$ the studied groups were (27.66 $\pm 0.13, \quad 27.57 \pm 0.14$ and $27.63 \pm 0.11$ respectively). The mean plasma levels of LDL-C of the studied groups were $(90.51 \pm 0.26,90.57 \pm 0.26$ and $90.48 \pm$ 0.32 respectively).

Statistical analysis of lipid profile using one way ANOVA test showed no significant difference between the all studied groups.

Significant high plasma Hcy levels were recorded in group II compared to those of group I and II $(p>0.001)$ There was no significant differences between group I and III (Table 1).

The mean plasma levels of CRP in group II were significantly higher than those of group I and III (37.94 \pm 0.5 versus $20.26 \pm 0.33$ and $20.37 \pm 0.36, p<0.001$ respectively), but there was no significant differences of these levels between group I and III.
The mean plasma levels of NO of group II were significantly lowered than those of group I and III (17.83 \pm 0.49 versus $34.47 \pm \quad 0.71$ and $32.4 \pm 0.95, \quad \mathrm{P}>0.001, \quad$ respectively), however there was no significant differences between those of group I and III, Figure (2). The plasma levels of MDA in group II were significantly higher than those of group I and III (8.19 \pm 0.09 versus $6.56 \pm 0.09$ and $6.6 \pm .08$ respectively). No significance differences were detected between these levels of group I and III. The plasma levels of GSH of group II were significantly decreased than those of group I and III $(26.74 \pm 0.25$ versus $39.64 \pm 0.33$ and $39.38 \pm 0.3$ respectively)Table (1). These levels of group I did not differ from those of groups II\&III.

Table (1) showed that the plasma levels of MCP-1 in group II were significantly higher than those of group I and III $(42.77 \pm 0.27$ versus $16.7 \pm 0.31$ and $16.84 \pm 0.18, \mathrm{p}<0.001$ respectively). No significance differences were detected between these levels of group I and III. The mean plasma levels of IL-6 in group II were significantly higher than those of group I and III (454.1 \pm 1.78 versus $282.4 \pm 1.98$ and $283.2 \pm 1.93, \mathrm{p}<0.001$ respectively), but the mean plasma levels of IL-6 of group I did not differ 
significantly from those of group III.Table (1)

\section{OTR expression:}

RT-PCR was used to investigate the effect of oxytocin administration to adult male rats on OTR transcripts in the rat aorta. As shown in Fig.3 (A), external OT treatment to adult male rats of group III augmented aortic OTR mRNA significantly $(P<0.001)$ than those of group I and II - No significant differences between aortic OTR mRNA in group I and II. Fig 3 (B): Specific bands of predicted length and increasing exponentially (until 45 cycles at $370 \mathrm{bp}$ ) were obtained with OTR specific primers in group III which in not indicated in group I and II.

\section{Histopathological results:}

Group I: The wall of the aorta in the rats showed normal architecture with normal 3 layers a) Tunica intima with characteristic endothelial layer and delicate sub endothelial connective tissue), Tunica media that is formed of several layers of smooth muscle fibers intermingled with large amount of elastic fibers. c)Tunica adventia is formed of loose connective tissues rich in elastic fibers.(Figure 4 A)

Immunohistochemical method for detection of NF- $\kappa \mathrm{B}$ p 65 demonstrates minimal reaction. (Figure $5 \mathrm{E}$ )

Group II: The wall of the aorta of group II (Figure 4 B) shows thickening of the wall, loss of the normal histological architecture and marked irregularity in the endothelial layer, infiltration of the media with multiple histocytes, endothelial ulceration (Figure $4 \mathrm{C}$ ).

The detection of NF- $\mathrm{B}$ p65 in the aorta isolated from this group demonstrates highly positive reaction in the endothelial cell.(figure 5F)

Group III: The thickness of the walls of the aortas and histological structure of this group similar to those of the control group (Figure $4 \mathrm{D}$ ). The

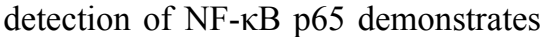
in the aorta isolated from this group demonstrates a weak positivity slightly higher than the control group. (Figure $5 \mathrm{G}$ ).

Table (1): Levels of plasma total Homocysteine (umol/l), MDA (ng/ml), CRP $(\mathrm{ng} / \mathrm{ml})$ and MCP-1 $(\mathrm{ug} / \mathrm{ml})$ in all studied groups

\begin{tabular}{|c|c|c|c|}
\hline Parameters Groups & Group I & Group II & Group III \\
\hline Hcy (umol/L) & $10.76 \pm 0.17$ & $18.36 \pm 0.3^{a, b}$ & $10.9 \pm 0.17^{\mathrm{c}}$ \\
\hline MDA $(n g / m l)$ & $6.6 \pm 0.09$ & $8.19 \pm 0.09^{a, b}$ & $6.6 \pm 0.08^{c}$ \\
\hline GSH (mg/ml) & $39.46 \pm 0.33^{d}$ & $26.74 \pm 0.25$ & $39.38 \pm 0.3$ \\
\hline CRP (ng/ml) & $20.26 \pm 0.33$ & $37.94 \pm 0.5^{\mathrm{a}, \mathrm{b}}$ & $20.37 \pm 0.36^{c}$ \\
\hline MCP-1(ug/ml) & $16.7 \pm 0.31$ & $42.77 \pm 0.27^{\mathrm{a}, \mathrm{b}}$ & $16.84 \pm 0.18^{\mathrm{c}}$ \\
\hline IL-6 (pg/ml) & $282.4 \pm 1.98$ & $454.1 \pm 1.78^{\mathrm{a}, \mathrm{b}}$ & $283.2 \pm 1.93^{c}$ \\
\hline
\end{tabular}

Data are expressed as mean \pm S.E.M.

a: $\mathrm{p}<0.001$ as compared to group $\mathrm{I}$.

b: $\mathrm{p}<0.001$ as compared to group III

c: non significant as compared to group I $\quad \mathrm{d}$ : $\mathrm{p}<0.001$ as compared to group II 


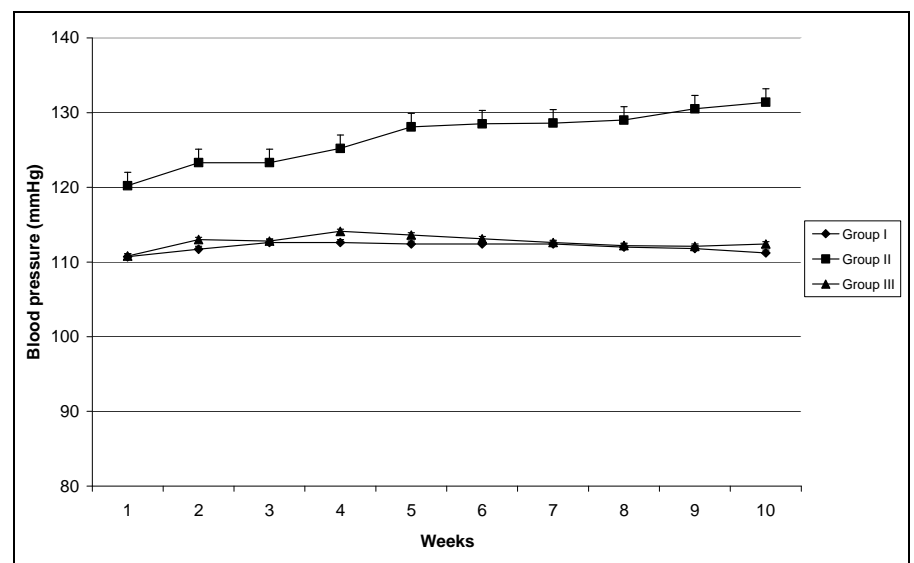

Fig(1): Systolic blood pressure (SBP) $\mathrm{mmHg}$ in all studied groups through the weeks of the study. The mean SBP values of group II were significantly higher than those of group I\& II. No significant differences were detected between the mean of SBP values of group I\&III.

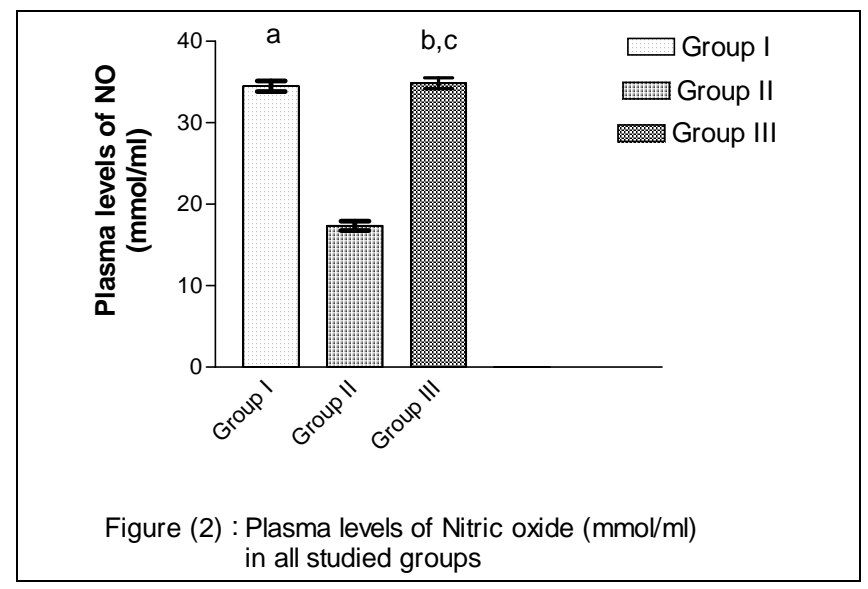

a: $p>0.001$ as compared to group II c: non significant as compared to group I

b: $p>0.001$ as compared to group II 


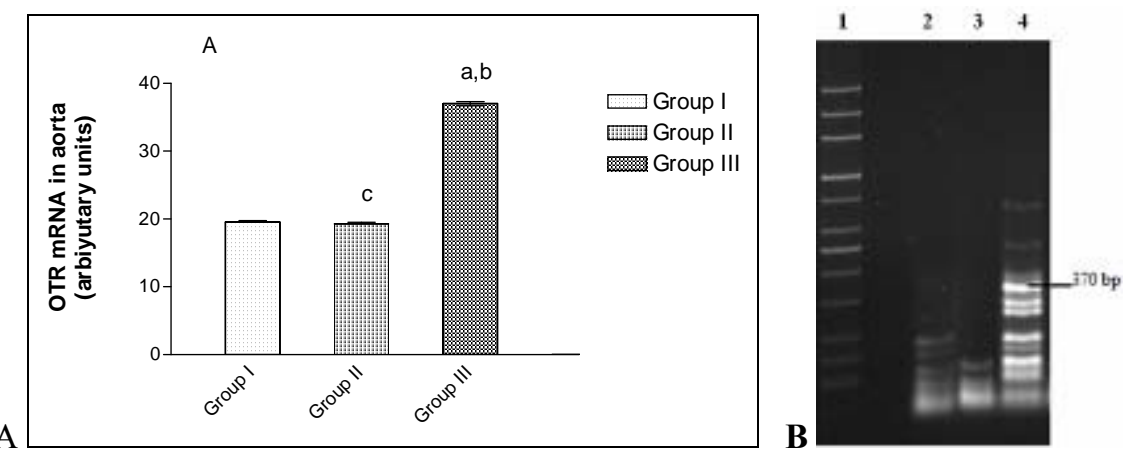

Figure (3) A: OT treatment enhances OTR mRNA in aorta of group III,a:p $<0.001$ as compared to group I, b:p $<0.001$ as compared to group II, c: non significant as compared to group I. (B): PhosphorImager analysis of RT-PCR amplification using specific oligonucleotide primers for OTR mRNA in the aorta of control, adult male rats supplemented with methionine and adult male rats treated with oxytocin. Total RNA isolated from aorta was used for RT-PCR reactions as described in Materials and Methods. Lane 1 from the left is the 1-kb ladder control; lane 2: group I, lanes 2: group II, and 3 : group III correspond to the primers specific for OTR at 370bp.
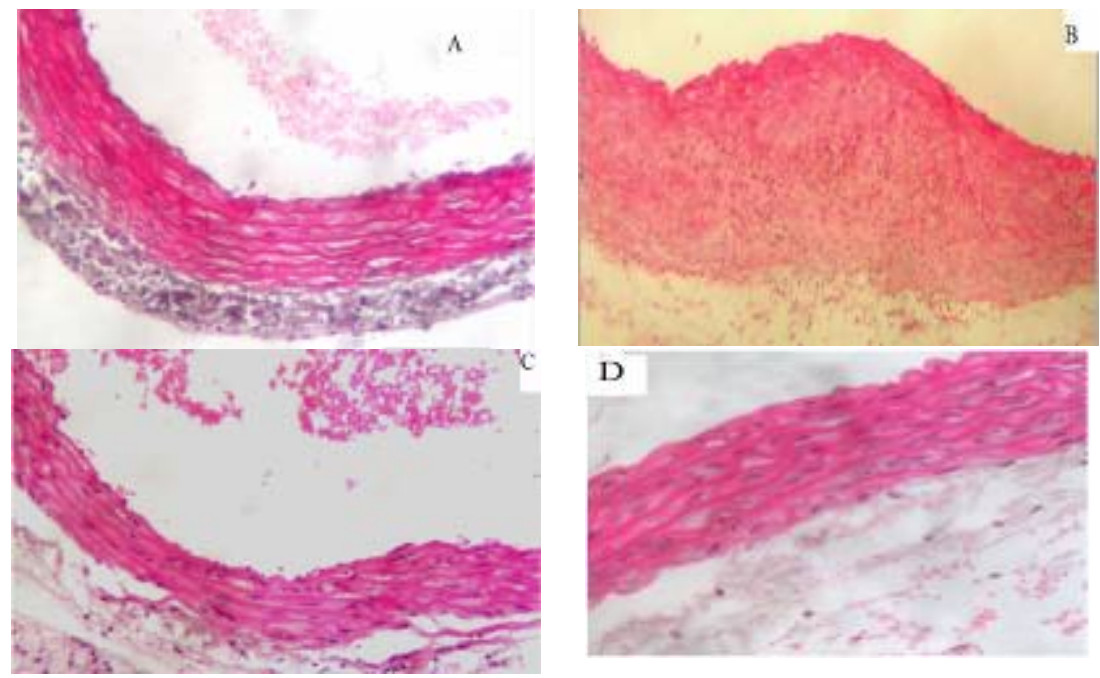

Figure (4): Photograph of transverse sections of the aorta:

(A): Transverse section of the aorta of group I showing normal histological structures. (B): Transverse section of the aorta of group II showing loss of normal architecture with infiltration by histocytes

(C): Transverse section of the aorta of group II showing ulceration of the endothelium.

(D): Transverse section of the aorta of group III showing histological structures nearly similar to those of group I. 


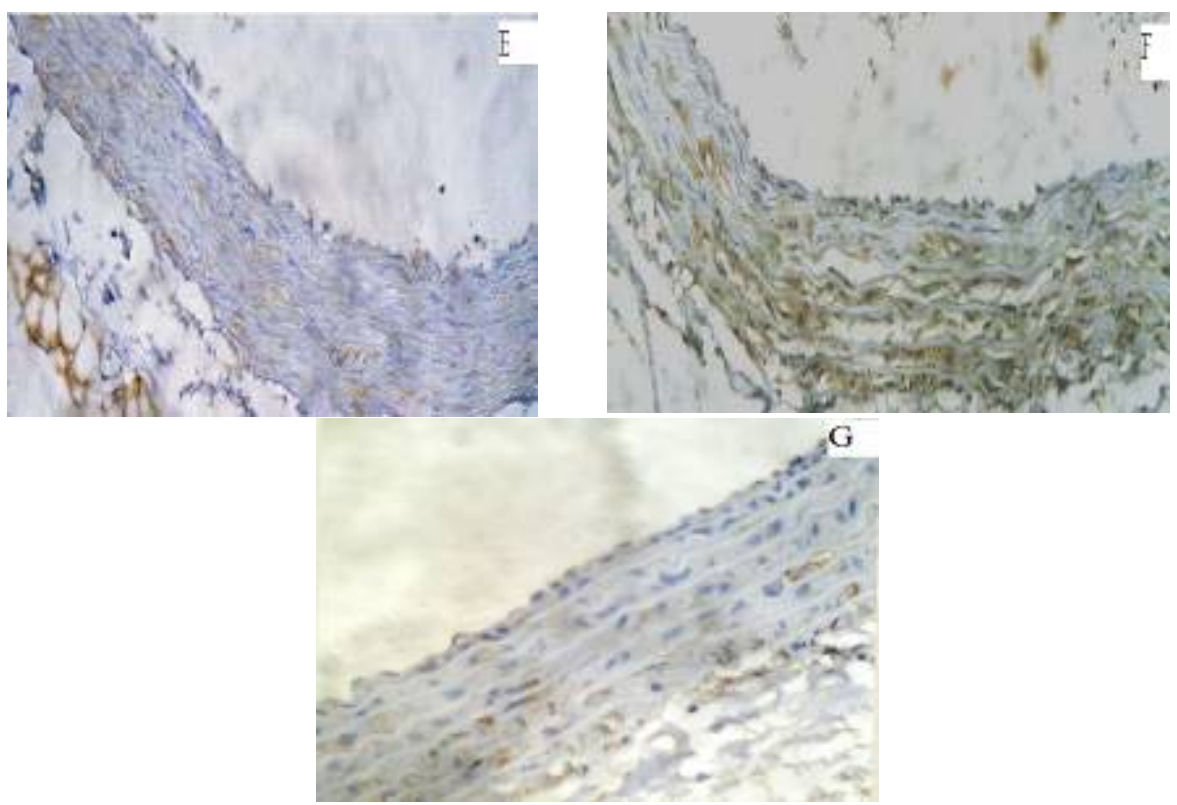

Figure (5) Immunohistochemical staining of sections from rat aortas:

(E):Normal expression of NF- $\mathrm{KB}$ in the group I

(F): Marked activation of NF- $\mathrm{BB}$ by methionine supplementation to adult male rats in group II.

(G): Decreased activation of NF- $\kappa$ B toward normal by treatment of the male rat by oxytocin in group III

\section{DISCUSSION}

The present study was designed to examine the effect of peripheral OT administration on the proinflammatory reaction that leads to atherosclerosis in adult rat model.

In group II where methionine was supplemented in diet to the adult male rats, the plasma levels of total homocysteine were significantly increased than those of the other studied groups which was explained by Hirche et al. ${ }^{(22)}$ who reported that methionine was metabolized into homocysteine .In addition, methionine and its intermediate product can inhibit homocysteine methyltransferase and thereby block the metabolism of Hcy.

HHcy causes oxidant stress by effects on cellular respiration ${ }^{(23)}$. This finding supports the results of the present study as the plasma levels of $\mathrm{NO}$ and GSH were significantly lower and levels of MDA of group II were increased significantly than those of group I and III. However, OT administration to group III increased the plasma levels of NO and GSH and decreased the plasma levels of MDA to normal. The present results demonstrate that oxytocin administration prevented both lipid 
peroxidation and GSH depletion thereby supports the maintenance of cellular integrity ${ }^{(24)}$. It appears that the protective effect of OT involves the maintenance of antioxidant capacity in protecting the tissues against oxidative stress .In addition, it was previously demonstrated that oxytocin leads to the release of $\mathrm{NO}^{(25)}$.

Oxidative stress may contribute to the deleterious effects of Hcy. Homocysteine induces endothelial cell injury through an oxidant-mediated mechanism ${ }^{(26)}$. Oxidative stress can stimulate the activation of NF- $\kappa \mathrm{B}$, which plays a pivotal role in the regulation of many genes involved in the inflammatory response. Various genes whose products are putatively involved in the atherosclerotic process are regulated by NF- $\kappa B$, such as MCP-1 and so forth ${ }^{(27)}$. and this explain the pathological results of the present results as there was significant increase of the expression of NF- $\mathrm{kB}$ in the aorta of the rats of group II and significant increased levels of CRP \& MCP-1 of this group than those of group I\&III. This indicates that the oxidative stress-NF- $\mathrm{kB}$ pathway promotes the expression of MCP-1. MCP-1 is a potent chemoattractant protein that stimulates the migration of monocytes into the intima of the arterial walls in the inflammatory response. One of the important early features of AS is monocyte infiltration into the injured arterial wall, followed by differentiation into macrophages. These macrophages then take up large amounts of lipids and become foam cells $^{(28)}$.

The decrease in neutrophil infilteration in response to oxytocin treatment of group III could be mediated by nitric oxide (NO) as it was previously demonstrated that oxytocin leads to the release of $\mathrm{NO}$, which then inhibits the adhesion and aggravation of neutrophil leukocytes ${ }^{(25)}$. That demonstrates that the pro- inflammatory responses due to methionine supplementation are alleviated by OT treatment through the mechanisms that involve an inhibitory action on tissue neutrophil infiltration, thereby inhibiting the release of ROS and inactivating inflammatory cytokines.

The present findings revealed that OT treatment activated the OT system in adult male rats as there were enhanced OTR mRNA and increased expressions of OTR in the aorta of rats of group III. This document that OTRs are abundant in aortic endothelial cells and this support that these OT and its receptors probably have a role in the damping of the early changes of atherosclerosis and OT system in the aorta may acts locally via an autocrine/paracrine mechanism in the vascular endothelium ${ }^{(29)}$. Peripheral administration of OT to the male rats of group III increased the OTR mRNA and the expression of OTR which indicates that OT administration has a direct mechanism through up regulation of its receptors suggesting that OTR may be one factor through which OT mediates its anti-inflammatory effects on the cardiovascular system.

The present results revealed that the plasma levels of (C, TG,HDL, VLDL) did not changed through the studied groups which indicates that the observed anti-inflammatory and anti-atherogenic effects of external OT are not due to changes in lipids. 
Group II exhibited a noticeable inflammatory reaction in term of significant elevated plasma levels of CRP and thickened media intima layer of aorta. In accordance of this finding, Ross $^{(30)}$ indicated that inflammation has a pivotal role in the development of atherosclerosis. Moreover a previous study suggested that measurement of the inflammatory marker CRP, may provide a useful method of assessing risk of cardiovascular disease in apparently healthy persons particularly when lipid levels are normal ${ }^{(31)}$.

The finding that plasma CRP levels were significantly lower in OT treated animals suggests a mechanism whereby visceral adipose tissue IL-6 secretion could be influencing levels of low grade inflammation systemically. This low-grade systemic inflammation is thought to directly impact lesion development through activation of macrophages and endothelial cells ${ }^{(25)}$.

The external administration of physiologically relevant doses of OT to rats to group III lowered BP significantly than the BP values of group II, this was explained by that the OT system can elicit parasympathetic stimulation via acetylcholine release that would act on muscarinic cholinergic receptors to increase intracellular $\mathrm{Ca}$ concentrations within vascular cells $^{(32)}$.

The present study revealed that OT treatment to the rats of group III decreased significantly the expression of NF-kB, which leads to decreased the plasma levels of the proinflammatory cytokine IL-6, MCP-1 and CRP toward normal levels through decrease their production.

The fact that OT was able to slow the initial development of these lesions in a region of high lesion prevalence suggests that it may be working through mechanisms important during lesion initiation ${ }^{(33)}$.

\section{Conclusion:}

OT has anti-inflammatory pathway in atherosclerosis. OT modulates the pathophysiological mechanisms thought to be involved in the exacerbation of atherosclerosis in animals as it is capable of dampening the pro-inflammatory cytokine release. This could prevent the endothelial dysfunction characteristic of the early stages of atherosclerosis in adult male rate through upregulation of its receptors in the aorta.

\section{Recommendation:}

The relationship between homocysteine and OTR in atherosclerosis must be investigated.

\section{REFERENCES}

1- Chorianpoulos E, Heger T, Lutz M, Frank D, Bea F, Katus HA, Frey N. FGF - inducible 14$\mathrm{Kda}$ protein (Fn14) is regulated via the RhoA/ ROCK kinase pathway in cardiomyocytes and mediates nuclear factor-kappaB activation by TWEAK. Basic Res Cardiol. 2010;105(2):301-313

2- Jankowski M, Wang D, Hajjar F, Mukaddam-Daher S, McCann SM, Gutkowska J. Oxytocin and its receptors are synthesized in the rat vasculature. PNAS. 2000; 97:6207-6211. 
3- Gutkowska J, Jankowsi M, Mukaddam-Daher S, McCann SM. Oxytocin is a cardiovascular hormone. 2000; 33:625-633.

4- Selhub J. Homocysteine metabolism. Annu Rev Nutr 1999; 19:217-46.

5- Breslow JL. Cardiovascular disease burden increases, NIH funding decreases. Nat Med 1997; 3:600-1.

6- McCully KS. Homocysteine and vascular disease. Nat Med 1996; 2:386-9.

7- Hofmann MA, Lalla E, Lu Y, Gleason MR, Wolf BM, Tanji N,Ferran Jr LJ, Kohl B, Rao V and Kisiel W. Hyperhomocysteinemia enhances vascular inflammation and accelerates atherosclerosis in a murine model. J Clin Invest. 2001; 107:675-683.

8- Zhang S, Day I, Ye S. Nicotine induced changes in gene expression by human coronary artery endothelial cells. Atherosclerosis. 2001; 154:277283.

9- Zhang R, Ma J, Xia M, Zhu H, and Ling W. Mild hyperhomocysteinemia induced by feeding rats diets rich in methionine or deficient in folate promotes early atherosclerotic inflammatory processes. Nutrient Metabolism. 2004; 134:825-830.

10- Petersson M, Lundeberg $T$, Sohlstrom A, Wilberg U, Uvnas-Moberg U. Oxytocin increases the survival of musculocutaneous flaps. 1998; 357:701-704.

11- Bıyıklı NK, Tugtepe $H$, Şener G, Velioğlu-Öğünc A, Çetinel
S, Midillioğlu Ş, Gedik N, Yeğen BC. Oxytocin alleviates oxidative renal injury in pyelonephritic rats via a neutrophil-dependent mechanism. Peptide.2006; 27:2249-2257.

12- Allian CC, Pooom LS, Chan SG, Richmond $W$ and Fu PC. Quantitative enzymatic colorimetric determination of total HDL, cholesterol in serum or plasma. Clinc Chem. 1974; 20:470- 475.

13- Wahlefeld AW. Ouantitative enzymatic colorimetric determination of triglycerides in serum or plasma .In: Methods of enzymatic analysis. Bergmeyer. H.U. Academic press. New York. 1974; vol.5.pp:1831-1835.

14- Finely PR. Enzymatic determination of HDL-C. Clin. Chem.1978;24 :931-934.

15- Friedewald WT, Levy RI and Fredrickson DS. Estimation of concentrations of low density lipoprotein cholesterol in plasma without use of the preparative ultracentrifuge .Clin. Chem.1972; 18:499-502.

16- Ding AH, Nathan $C F$ and Stuehr DJ. Release of reactive nitrogen intermediates and reactive oxygen intermediates from mouse peritoneal macrophages. Comparison of activity cytokines and evidences of independent production. Immuno. 1988; 141: 2407- 2412.

17- Ohkawa H, Ohishi, and Yagi K. Assay for lipid peroxides in animal tissues by thiobarbituric acid reaction. Anal. Biochem. 1979; 95:351-358. 
18- Jayatilleke E, Shaw S. A highperformance liquid chromatographic assay for reduced and oxidized glutathione in biological samples. Analytical Biochemistry 1993;214(2), 45257

19- Frantzen F, Faren AL. An enzyme conversion immunoassay for determinating total homocystiene in plasma and serum Clinc Chem.1998; 44:311.

20- Brady, M., Bhatia, M., Christmas, S., Boyd, M. T., Neoptolemos, J. P., \&Slavin, J. (2002) Expression of the chemokines MCP-1/JE and cytokine induced neutrophil chemoattractant in early acute pancreatitis. Pancreas 25:260269.

21- Knapp GR and Miller MC.: Tests of statistical significance: Regression and Correlation. In: Clinical Epidemiology and Biostatistics $\quad 1^{\text {st }} \quad$ Eddition. Williams and Wilkins, Baltimoe, Maryland. 1992: 255-274.

22- Hirche FA,Schroder A, Knoth B, Stangl GI and Eder K. Effect of dietary methionine on plasma and liver cholesterol concentrations in rats and expression of hepatic genes involved in cholesterol metabolism .British Journal of Nutrition.2006;95: 879-888.

23- Gimpl G, Fahrenholz F. The oxytocin receptor system: structure, function, and regulation. Physiol Rev 2001; 81:629-683.

24- Loscalzo J. The oxidant stress of hyperhomocysteinemia. J Clin Invest, 1996; 98:5-7.
25- Iseri SO, Sener G, Saglam B, Gedik N, Ercan F, and Yegan BC. Oxytocin ameliorates oxidative colonic inflammation by neutrophil-dependent mechanism. Peptide. 2005; 26:483-491.

26- Moosmann B, Behl C. Secretory peptide hormones are biochemical antioxidants: structure-activity relationship. Mol Pharmacol 2002;61: 260-8.

27- Hagar, H. H. Folic acid and vitamin B12 supplementation attenuates isoprenaline-induced myocardial infarction in experimental hyperhomocysteinemic rats. Pharmacol. Res.2002; 46: 213-219.

28- Bowie, A. \& O'Neill, L. A. Oxidative stress and nuclear factor kappaB activation: a reassessment of the evidence in the light of recent discoveries. Biochem. Pharmacol. 2000;59: 13-23.

29- Wang D, Gutkowska J, Marcinkiewicz $M$, Rachelska G, Jankowski M. Genistein supplementation stimulates the oxytocin system in the aorta of ovariectomized rats. Cardiovascular Research. 2003; 57:186-194.

30- Ross R. Atherosclerosis - an inflammatory disease. New England Journal of Medicine 1999; 340(2):115-26.

31- Ridker PM, Hennekens CH, Buring JE, Rifai N. C-reactive protein and other markers of inflammation in the prediction of cardiovascular disease in women - New England Journal of Medicine. 2000;342:836-843. 
32- Daniel A, Angela S, Armando JM, Larry GB, Julia Z, Edward EH, Julie G, Crystal MN, Neil S. Oxytocin attenuates atherosclerosis and adipose tissue inflammation in socially isolated Apo E-/- Mice. Psychosomatic Medicine. 2010; 72:376-382.
33- Wang, G., Woo, C.W.H., Sung, F.L., Siow, Y.L. \& Karmin O. Increased monocyte adhesion to aortic endothelialium in rats with hyperhomocysteinemia role of chermokine and adhesion molecules. Arterioscler. Thromb. Vasc. Biol. 2002; 22: 1777-1783.

\title{
دور الأوكسيتوسين في ابطاء حدوث الالتهابات المصاحبة لتصلب الثرايين ألمبكر لاي ذكور الفئران البالغة
}

\author{
مروة عبل العزبيز أحدد - جيهان محد العسبيليث

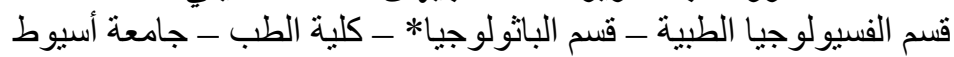

تهدف هذه الدراسة الي معرفة تأثير حقن هرمون الأوكسيتوسين علي الالتهاب وتصلب الثرائن ائلاين لدي ذكور

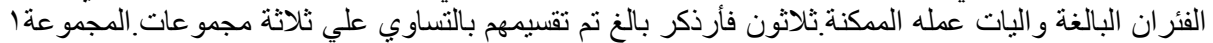



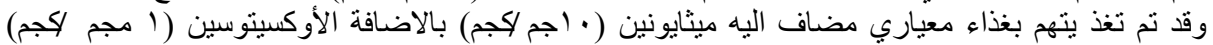

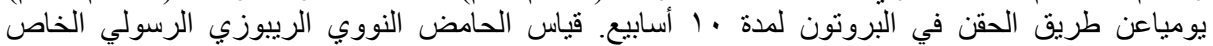

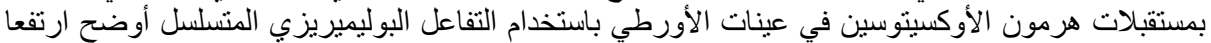

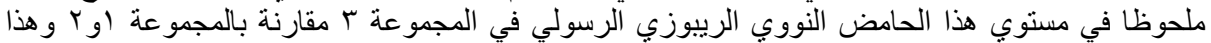
الارتفاع له دلالة احصائية عالية.

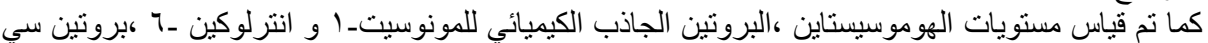

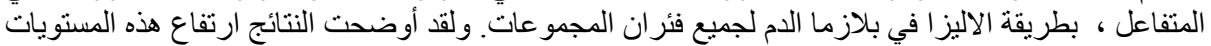



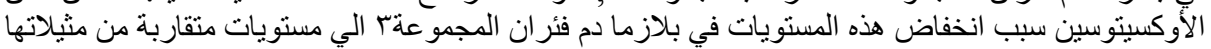
في المجمو عة اوهي المجموعة الضابطة.

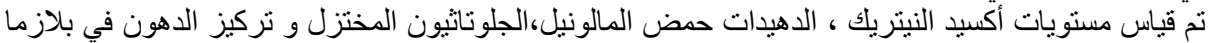

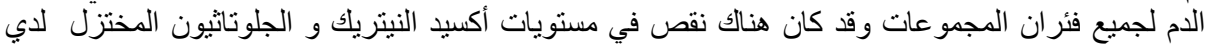

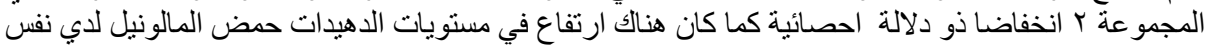

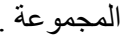

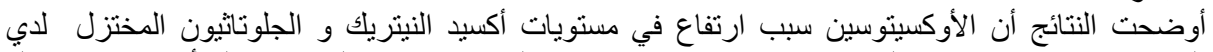

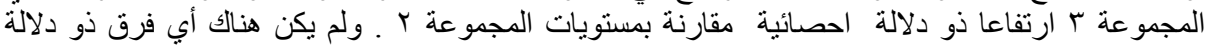

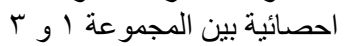

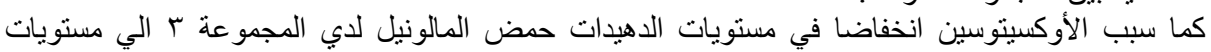

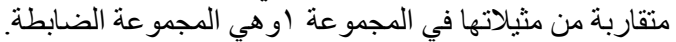

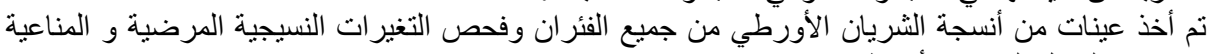

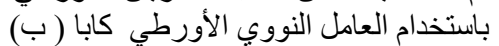

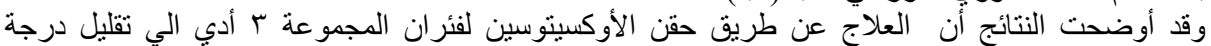

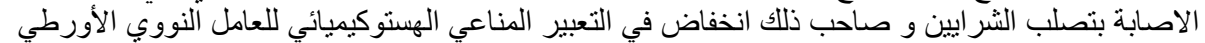

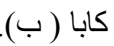
وقد خلص البحث الي أن الأوكسيتوسين له دور مضاد للالتهاب في مرض تصلب الباد الثرايين ويعمل علي ابطاء

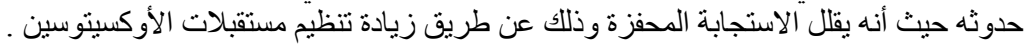

